\title{
Trends in hydrological variables in large basins in Tibetan Plateau
}

\author{
Hongxia Lia, Yongqiang Zhang ${ }^{\mathrm{b}}$, Fapeng Lic, Guanghua Qin a and Xin Wanga \\ a State Key Laboratory of Hydraulics and Mountain River Engineering, Sichuan University, Chengdu, \\ 610065, China; \\ ${ }^{b}$ CSIRO Land and Water Flagship, ACTON 2601, Canberra, Australia \\ ${ }^{c}$ Development Research Center, Ministry of Water Resources, Beijing 100038, China \\ Email: yongqiang.zhang@,csiro.au
}

\begin{abstract}
The Tibetan Plateau is the source area of many major rivers in Asia, including the Indus River, Ganges River, Brahmaputra River, Yangtze River and Yellow River. It plays a key role in both hydrologic cycle and climate in eastern and south-eastern Asia. Recent studies have shown that the majority of the plateau area has experienced significant warming since the mid-1950s. This paper investigates hydrological and climatic trends for six large river basins (Yalung Zangbo River, Salween River, Mekong River, Tongtianhe River, Yalongjiang River and Yellow River) in the Tibetan Plateau during 1956-2013, and determines whether the changes in streamflow in these basins are mainly driven by the variation of climatic elements (precipitation and temperature). Our results show that during the past multi-decades, the six river basins did not exhibit distinct trends in annual streamflow $(\mathrm{p}>0.05)$. Yarlung Tsangpo River at Nuxia station and Yellow River at Tangnaihai station showed a slightly decreasing trend $\left(-0.009 \mathrm{~mm} \mathrm{yr}^{-2},-0.19 \mathrm{~mm} \mathrm{yr}^{-2}\right)$ in annual streamflow while others showed a slightly increasing trend. Annual mean temperature and precipitation at all stations except for Luning showed noticeably increasing trends. The impact of global warming on streamflow is complicated. On the one hand, annual evaporation could increase under warmer and drier air conditions, which will result in decreasing streamflow. On the other hand, meltwater will increase under global warming, which will increase streamflow. Our results suggest that climate warming in the Tibetan Plateau has speeded up the water cycle, indicated by the slight increase in streamflow. Further hydrological modelling studies should be conducted to quantify future streamflow changes and their uncertainty across the Tibetan Plateau.
\end{abstract}

Keywords: Tibetan Plateau, climate change, streamflow, precipitation, temperature 


\section{INTRODUCTION}

The Tibetan Plateau is the highest plateau in the world, which has an average altitude of $4700 \mathrm{~m}$. It plays an important role in hydrologic cycle and climate in east and south-eastern Asia (Yao et al., 2010). The Tibetan Plateau is sensitive to global climate change (Krause et al., 2010; Immerzeel et al., 2010), which has experienced strong warming in the past 50 years (You et al., 2007; Yang et al., 2011; Li et al., 2013). For example, some studies showed that precipitation increased for most areas in the Tibetan Plateau (Wang et al., 2008; Xu et al., 2008); the air temperature significantly increased from 1960 to 2007; and a pan evaporation paradox is reported with a reference evapotranspiration decrease and pan evaporation increase (Liu et al., 2011; Zhang et al., 2007).

The Tibetan Plateau is also the source area of many major rivers in Asia, including the Indus River, Ganges River, Brahmaputra River, Yangtze River and Yellow River. These rivers are known as Asian water tower (Immerzeel et al., 2010 and Li et al., 2014). The major river systems in the Tibetan Plateau are expected to be impacted by climate change and climate variability (Immerzeel et al., 2010). Changes in the streamflow and watershed hydrology in the Tibetan Plateau have become increasingly important for water resources management. Therefore, it is important to explore trends in hydrological variables in the Tibetan Plateau for a better understanding of surface water availability.

Many studies have reported streamflow variability in the Tibetan Plateau at different spatial scales. However, most studies focused on streamflow variability in single river basin. For example, Li et al (2014) explored the changes in runoff for upstreams of Yellow River. Cao et al (2011) investigated climate change impact on hydrological processes over the Yangtze River basin. There are few studies conducted for investigating hydrological trends for various large basins.

The main objectives of this study are (1) to investigate trends in hydrological variables in six large river basins (Yalung Zangbo River, Salween River, Mekong River, Tongtianhe River, Yalongjiang River and Yellow River) with three rivers flowing into the Pacific Ocean and other three flowing into the Indian Ocean and (2) to understand possible causes for inter-annual streamflow variability.

\section{STUDY AREA AND DATA}

\subsection{Study area}

The Tibetan Plateau is approximately $2.5 \times 10^{6} \mathrm{~km}^{2}$ and covers most of the Tibet Autonomous Region and Qinghai Province in China. The outflow region of Tibetan Plateau is about $1.25 \times 10^{6} \mathrm{~km}^{2}$, which is about $50 \%$ of the Tibetan Plateau.

In this paper, six stations for the six major rivers located in the Tibetan Plateau were selected. They are Yalung Zangbo River at Nuxia station, Salween River at Jiayuqiao station, Mekong River at Qamdo station, Tongtianhe River at Zhimenda station, Yalongjiang River at Luning station, and Yellow River at Tangnaihai station (Table 1 and Figure 1). The total area of the six basins is about $0.68 \times 10^{6} \mathrm{~km}^{2}$, which is about $54.6 \%$ of the outflow region of the Tibetan Plateau.

Table 1. Summary of characteristics of the 6 stations used in this study.

\begin{tabular}{|c|l|l|l|l|l|l|}
\hline No. & Station & Longitude & Latitude & Basin & Stream & Area $\left(\times 10^{6} \mathrm{~km}^{2}\right)$ \\
\hline 1 & Nuxia & 94.5667 & 29.4667 & Yarlung Tsangpo & Yarlung Tsangpo & 0.19 \\
\hline 2 & Jiayuqiao & 96.2333 & 30.8667 & Salween & Salween & 0.07 \\
\hline 3 & Qamdo & 97.1667 & 31.1500 & Mekong & Mekong & 0.05 \\
\hline 4 & Zhimenda & 97.22 & 33.03 & Yangtse & Tongtianhe & 0.14 \\
\hline 5 & Luning & 101.87 & 28.45 & Yangtse & Yalongjiang & 0.11 \\
\hline 6 & Tangnaihai & 100.1500 & 35.5000 & Yellow & Yellow & 0.12 \\
\hline
\end{tabular}




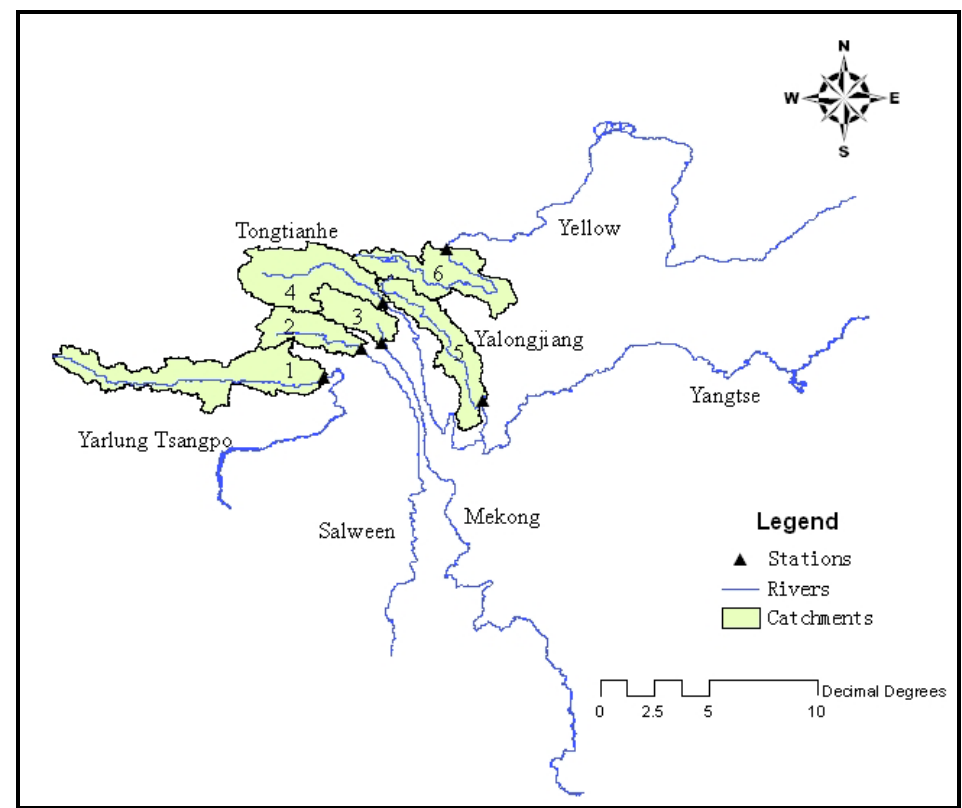

Figure 1. Location of the study area.

\subsection{Climate data and streamflow data}

Daily time series of precipitation from 1979 to 2012 were obtained from Cold and Arid Regions Data Center of China (http://westdc.westgis.ac.cn/), which are at a spatial resolution of $0.1^{\circ} \times 0.1^{\circ}$. Daily time series of mean temperature from 1961 to 2007 were obtained from Asian Precipitation-Highly Resolved Observation (APHRO) (Xie et al., 2007), which are at a spatial resolution of $0.25^{\circ} \times 0.25^{\circ}$.

The streamflow data covers the period from 1956 to 2013 and were sourced from the Hydrology and Water Resource Survey (HWRS) in the Tibetan Autonomous Region (TAR) of China (Table 2).

Table 2. Climate data and streamflow data of the 6 stations used in this study.

\begin{tabular}{|c|l|c|c|c|}
\hline & \multicolumn{1}{|c|}{ Station } & Streamflow & Precipitation & Temperature \\
\hline 1 & Nuxia & $1956-2012$ & $1979-2012$ & $1961-2007$ \\
\hline 2 & Jiayuqiao & $1980-2010$ & $1979-2012$ & $1961-2007$ \\
\hline 3 & Qamdo & $1968-2000$ & $1979-2012$ & $1961-2007$ \\
\hline 4 & Zhimenda & $1959-2008$ & $1979-2012$ & $1961-2007$ \\
\hline 5 & Luning & $1956-2008$ & $1979-2012$ & $1961-2007$ \\
\hline 6 & Tangnaihai & $1956-2013$ & $1979-2012$ & $1961-2007$ \\
\hline
\end{tabular}

\section{RESULTS AND DISCUSSION}

Figure 2 shows trends in annual streamflow for the six basins during $1956-2013$. The six river basins did not exhibit distinct trends $(\mathrm{p}>0.05)$. Annual streamflow at Jiayuqiao, Qamdo, Zhimenda and Luning stations showed a slightly increasing trend $\left(1.50 \mathrm{~mm} \mathrm{yr}^{-2}, 0.60 \mathrm{~mm} \mathrm{yr}^{-2}, 0.21 \mathrm{~mm} \mathrm{yr}^{-2}, 0.39 \mathrm{~mm} \mathrm{yr}^{-2}\right)$, respectively.

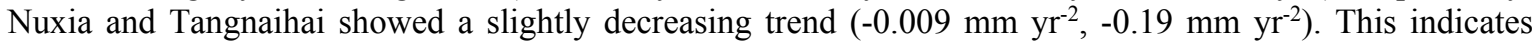
some regional difference in streamflow trends. The rivers in the southeastern Tibetan Plateau exhibited an increasing trend, while Yarlung Tsangpo River in the southern Tibetan Plateau and the Yellow River basin in the northeastern Tibetan Plateau exhibited a slightly decreasing trend. 

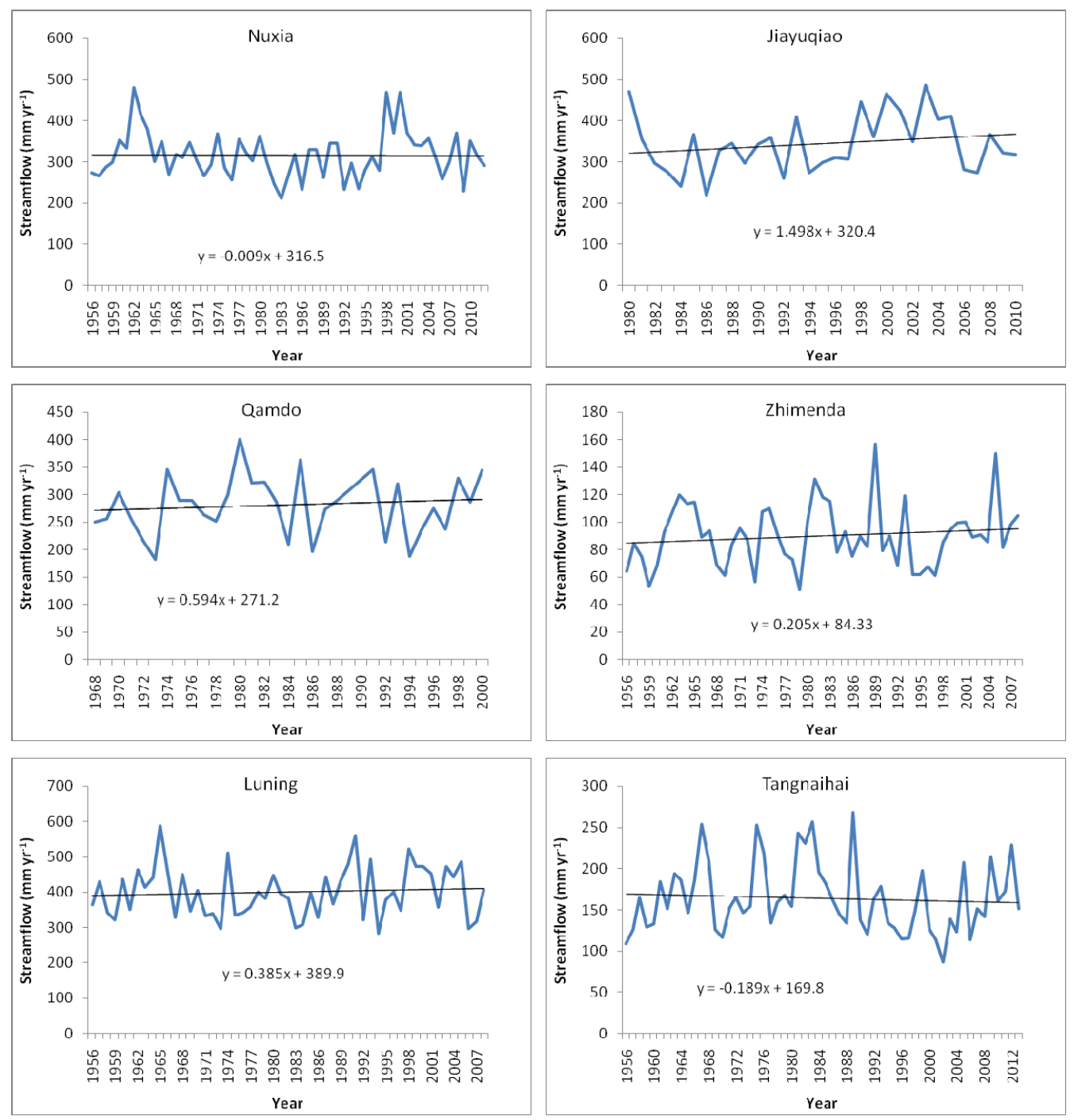

Figure 2. Trends of annual streamflow of six stations in Tibetan Plateau.

The trends in precipitation and air temperature were examined to identify their impacts on streamflow trends in the Tibetan Plateau. For precipitation, all stations except for Luning showed distinct increasing trend (2.13 to $4.22 \mathrm{~mm} \mathrm{yr}^{-2}, \mathrm{p}<0.05$ ) during the period of 1979-2012 (Figure 3, Table 3). For temperature, all stations except for Luning showed distinct warming trend $\left(0.022\right.$ to $\left.0.046{ }^{\circ} \mathrm{C} \mathrm{yr}^{-1}, \mathrm{p}<0.05\right)$ during the period of $1961-$ 2007 (Figure 3, Table 3), which was much stronger than the global warming rate $\left(0.026^{\circ} \mathrm{C} \mathrm{yr}^{-1}\right)$ (IPCC, 2014).
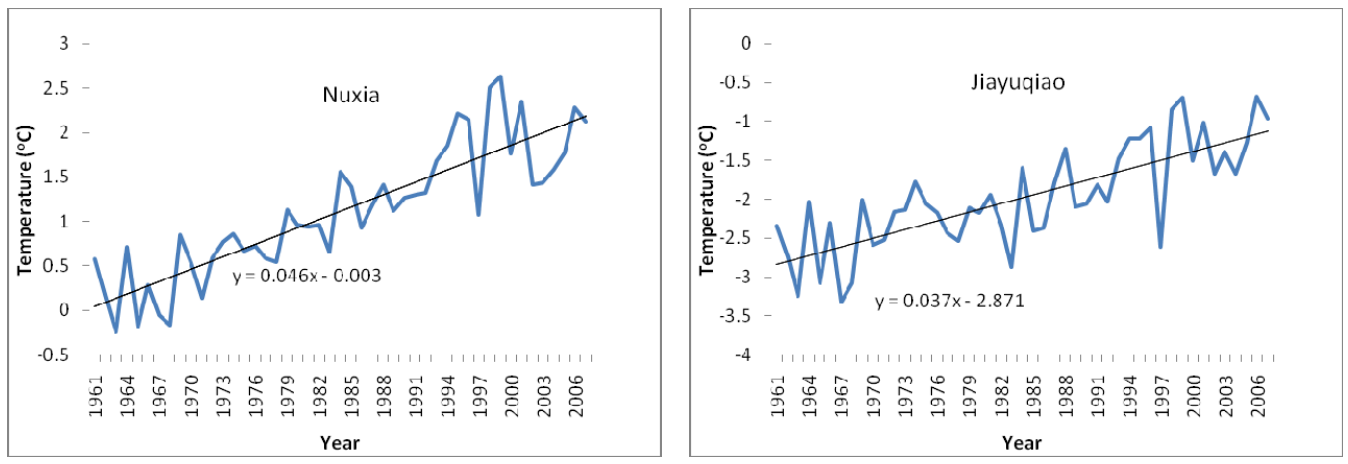

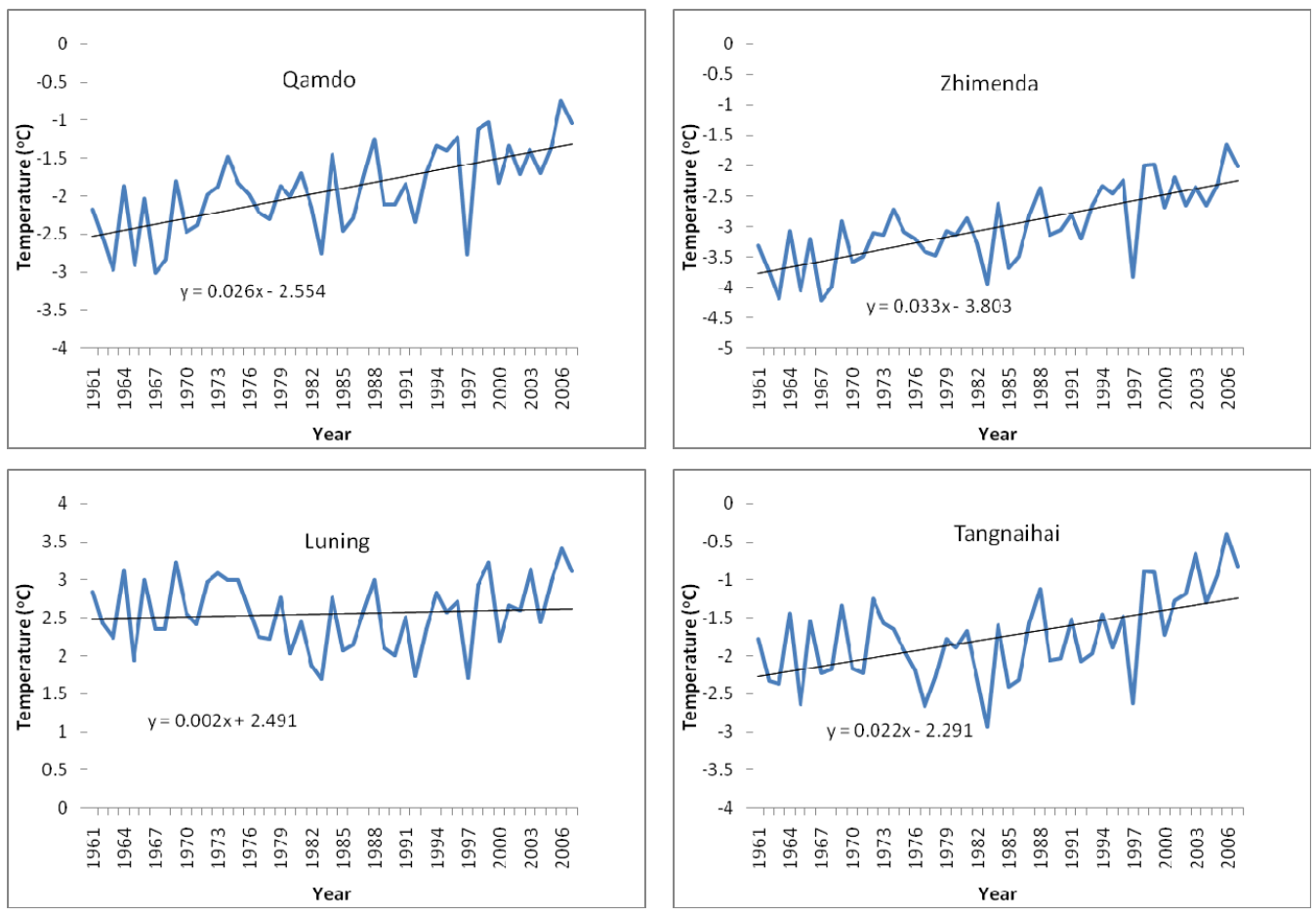

Figure 3. Trends of annual temperature of six stations in Tibetan Plateau.
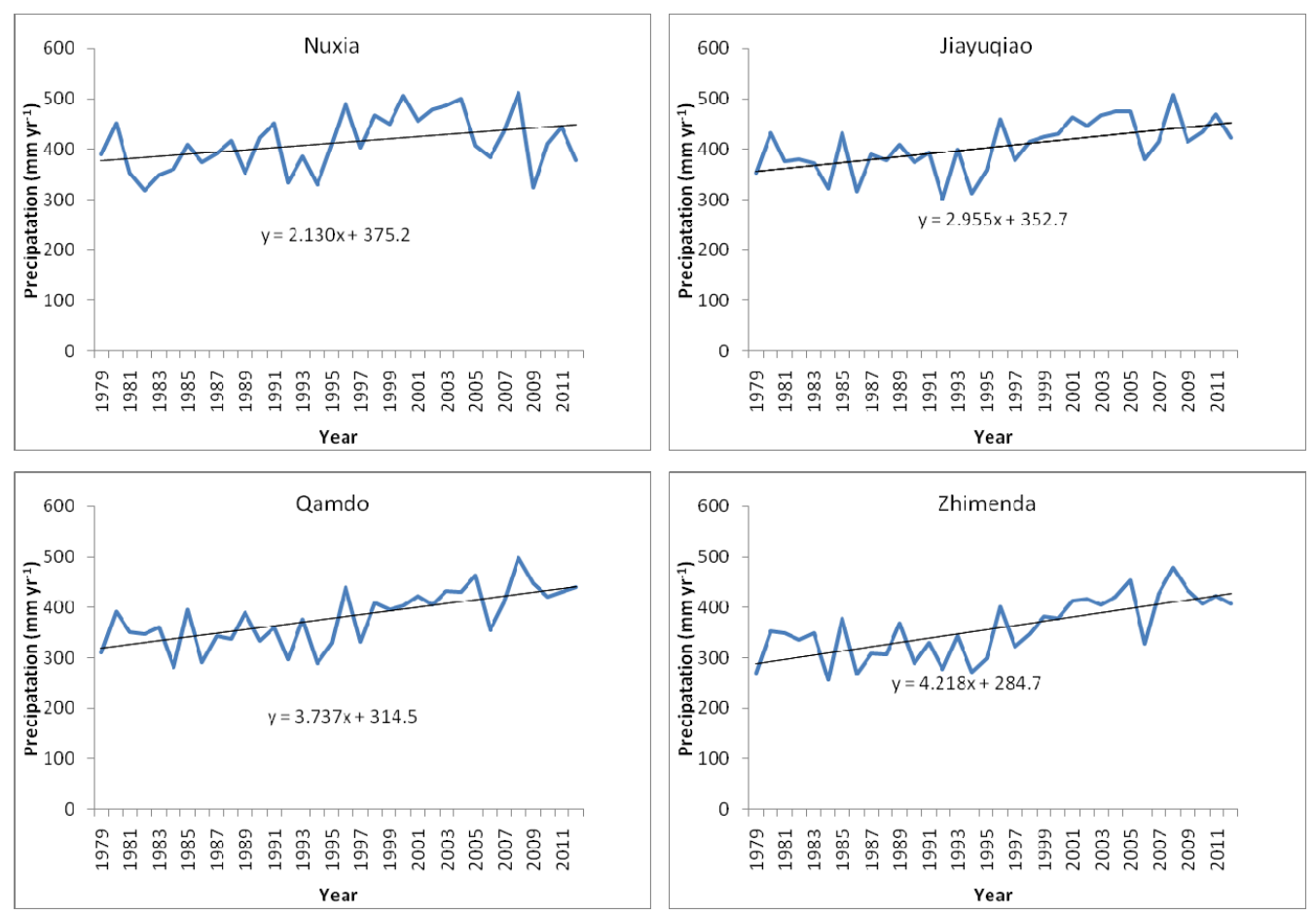

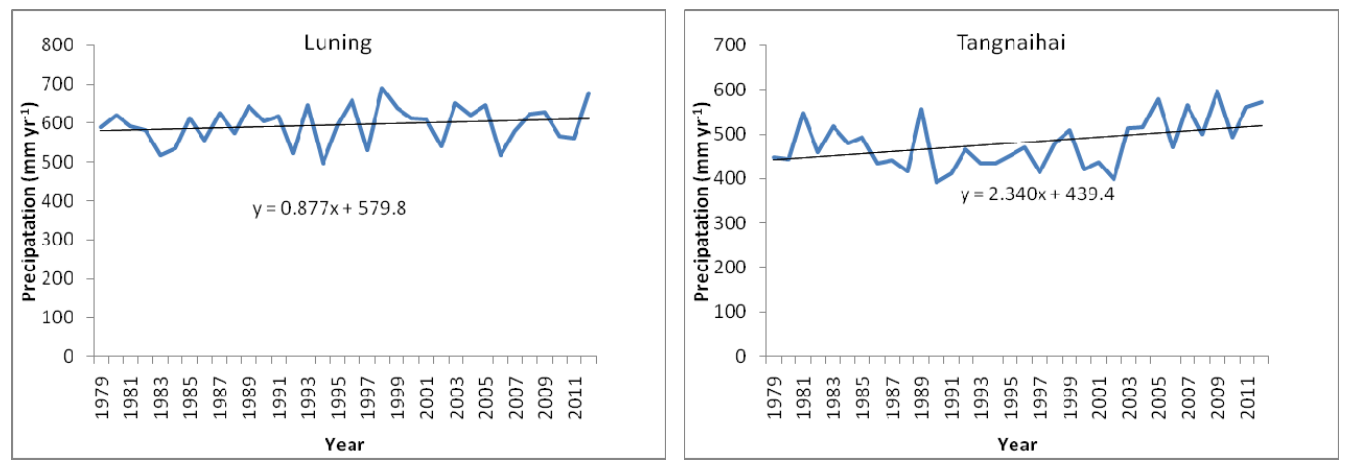

Figure 4. Trends of annual precipitation of six stations in Tibetan Plateau.

Table 3. Climate and streamflow trends of the 6 stations used in this study (all the data).

\begin{tabular}{|l|c|c|c|c|c|c|}
\hline \multirow{2}{*}{ Station } & \multicolumn{2}{|c|}{ Streamflow } & \multicolumn{2}{c|}{ Precipitation } & \multicolumn{2}{c|}{ Temperature } \\
\cline { 2 - 7 } & $\mathrm{p}$ & Slope $\left(\mathrm{mm} \mathrm{yr}^{-2}\right)$ & $\mathrm{p}$ & Slope $\left(\mathrm{mm} \mathrm{yr}^{-2}\right)$ & $\mathrm{p}$ & Slope $\left({ }^{\circ} \mathrm{C} \mathrm{yr}^{-1}\right)$ \\
\hline Nuxia & $>0.05$ & -0.009 & $<\mathbf{0 . 0 5}$ & 2.13 & $<\mathbf{0 . 0 5}$ & $\mathbf{0 . 0 4 6}$ \\
\hline Jiayuqiao & $>0.05$ & 1.50 & $<\mathbf{0 . 0 5}$ & 2.96 & $<\mathbf{0 . 0 5}$ & $\mathbf{0 . 0 3 7}$ \\
\hline Qamdo & $>0.05$ & 0.60 & $<\mathbf{0 . 0 5}$ & 3.74 & $<\mathbf{0 . 0 5}$ & $\mathbf{0 . 0 2 6}$ \\
\hline Zhimenda & $>0.05$ & 0.21 & $<\mathbf{0 . 0 5}$ & 4.22 & $<\mathbf{0 . 0 5}$ & $\mathbf{0 . 0 3 3}$ \\
\hline Luning & $>0.05$ & 0.39 & $>0.05$ & 0.88 & $>0.05$ & 0.002 \\
\hline Tangnaihai & $>0.05$ & -0.19 & $<\mathbf{0 . 0 5}$ & 2.34 & $<\mathbf{0 . 0 5}$ & $\mathbf{0 . 0 2 2}$ \\
\hline
\end{tabular}

To identify the impacts of climate change on streamflow, we redid the trend analysis for streamflow, precipitation and mean air temperature with the time-series data available for all the three variables (Table 4). Basically, the results shown in Table 4 are very similar to the results shown in Figures 2-4 and Table 3. However, annual streamflow at the Tangnaihai station showed more significant decreasing trend $\left(-2.76 \mathrm{~mm} \mathrm{r}^{-}\right.$ $\left.{ }^{2}\right)$ than those in Table $3\left(-0.19 \mathrm{~mm}\right.$ per $\left.\mathrm{yr}^{-2}\right)$. Also, the temperature showed a more significant increasing trend than those shown in Table 3, which indicated it was warmer in the recent years.

Table 4. Climate and streamflow trends of the 6 stations used in this study (data of the same period).

\begin{tabular}{|c|c|c|c|c|c|c|}
\hline \multirow{2}{*}{ Station } & \multicolumn{2}{|c|}{ Streamflow } & \multicolumn{2}{|c|}{ Precipitation } & \multicolumn{2}{|c|}{ Temperature } \\
\hline & $\mathrm{p}$ & Slope $\left(\mathrm{mm} \mathrm{yr}^{-2}\right)$ & $\mathrm{p}$ & Slope $\left(\mathrm{mm} \mathrm{yr}^{-2}\right)$ & $\mathrm{p}$ & Slope $\left({ }^{\circ} \mathrm{C} \mathrm{yr}^{-1}\right)$ \\
\hline Nuxia & $>0.05$ & 2.35 & $<0.05$ & 3.46 & $<0.05$ & 0.042 \\
\hline Jiayuqiao & $>0.05$ & 2.28 & $<0.05$ & 2.95 & $<0.05$ & 0.047 \\
\hline Qamdo & $>0.05$ & -1.75 & $<0.05$ & 3.27 & $<0.05$ & 0.033 \\
\hline Zhimenda & $>0.05$ & -0.04 & $<0.05$ & 3.89 & $<0.05$ & 0.043 \\
\hline Luning & $>0.05$ & 1.23 & $>0.05$ & 0.79 & $>0.05$ & 0.029 \\
\hline Tangnaihai & $<0.05$ & -2.76 & $>0.05$ & 1.04 & $<0.05$ & 0.047 \\
\hline
\end{tabular}

Results shown above indicate that precipitation and temperature impacts on trends in streamflow in the rivers in the Tibetan Plateau are complicated. On the one hand, annual evaporation could increase with warmer and drier air conditions, which will result in decrease in annual streamflow. On the other hand, glacier meltwater will increase under global warming, which will increase streamflow. The integrated impact from temperature and precipitation should be increasing streamflow. However, the glacier meltwater impact is evident in the rivers in the southern Tibetan Plateau where glacier water recharge accounts for noticeable percentage of total runoff. But the meltwater runoff for Yellow River at Tangnaihai station only accounts for $1.9 \%$ to total streamflow (Yang, 1991). This maybe the reason that streamflow in the Yellow river basin was decreased.

\section{CONCLUSIONS}

This paper investigates trends in streamflow and its two major drivers (precipitation and temperatures) for 6 large river basins in the Tibetan Plateau. Results showed that annual streamflow did not exhibit distinct 
trends, along with that four rivers basins (except for Yarlung Tsangpo River and Yellow River basins) exhibited a slightly increasing trend. Annual temperature and precipitation showed a distinct increasing trend, except for Yalongjiang River at Luning station. The results hint that the slightly increasing streamflow in the southeastern river basins may be caused by precipitation and the increased watermelt from glaciers. More hydrological modelling studies are being conducted to quantify causes for historical and future changes in streamflow in the Tibetan Plateau.

\section{ACKNOWLEDGMENTS}

This research was supported by the National Natural Science Foundation of China (No. 51209152), and the Open Fund (SKHL1406) supported by the State Key Laboratory of Hydraulics and Mountain River Engineering.

\section{REFERENCES}

Cao, L., Zhang, Y., Shi, Y. (2011). Climate change effect on hydrological processes over the Yangtze River basin. Quaternary International, 244, 202-210.

Immerzeel, W.W., van Beek, L.P.H., Bierkens, M.F.P. (2010). Climate change will affect the Asian water towers. Science, 328, 1382-1385. http://dx.doi.org/10.1126/ science.1183188.

IPCC (2014). Climate Change 2013-The physical science basis. THE INTERGOVERNMENTAL PANEL ON CLIMATE CHANGE, Geneva.

Krause, P., Biskop, S., Helmshrot, J., Flugel, W.A., Kang, S., Gao, T. (2010). Hydrological system analysis and modelling of the Nam Co basin in Tibet. Advances in Geosciences, 27, 29-36.

Li, B., Yu, Z., Song, K., Li, H. (2014). Effects of Climate Variations and Human Activities on Runoff in the Zoige Alpine Wetland in the Eastern Edge of the Tibetan Plateau. Journal of Hydrologic Engineering, 19(5), 1026-1035.

Li, F., Zhang, Y.Q., et al (2013): The impact of climate change on runoff in the southeastern Tibetan Plateau. Journal of Hydrology, 505 (2013) 188-201.

Li, F., Zhang, Y.Q., et al (2014): Runoff predictions in ungauged catchments in southeast Tibetan Plateau. Journal of Hydrology, 511, 28-38.

Liu, X., Zheng, H., Zhang, M., Liu, C. (2011). Identification of dominant climate factor for pan evaporation trend in the Tibetan Plateau. Journal of Geographical Sciences, 21, 594-608.

Wang, B., Bao, Q., Hoskings, B., Wu, G., Liu, Y. (2008). Tibetan Plateau warming and precipitation change in East Asia. Geophysical Research Letter, 35, L14702. http://dx.doi.org/10.1029/2008GL034330.

Xie, P., Yatagai, A., Chen, M., Hayasaka, T., Fukushima, Y., Liu, C., Yang, S. (2007). A gauge-based analysis of daily precipitation over East Asia. Journal of Hydrometeorology, 8, 607-626.

$\mathrm{Xu}, \mathrm{Z}$., Gong, T., Li, J. (2008). Decadal trend of climate in the Tibetan Plateau-regional temperature and precipitation. Hydrological Processes, 22, 3056-3065.

Yang, K., Ye, B.S., Zhou, D.G., Wu, B.Y., Foken, T., Qin, J., Zhou, Z.Y. (2011). Response of hydrological cycle to recent climate changes in the Tibetan Plateau. Climatic Change, 109, 517-534. http://dx.doi.org/10.1007/s10584-011-0099-4.

Yang, Z. (1991). Glacial. Resources of China, Gansu Science \& Technology Press, Lanzhou.

Yao, T., Li, Z., Yang, W., Guo, X., Zhu, L., Kang, S., Wu, Y., Yu, W. (2010). Glacial distribution and mass balance in the Yarlung Zangbo River and its influence on lakes. Chinese Science Bulletin, 55, 2072-2078. http://dx.doi.org/10.1007/ s1 1434-010-3213-5.

You, Q., Kang, S., Wu, Y., Yan, Y. (2007). Climate change over the Yarlung Zangbo River Basin during 1961-2005. J. Geog. Sci, 17 (4), 409-420. http://dx.doi.org/10.1007/s11442-007-0409-y.

Zhang, Y., Liu, C., Tang, Y., Yang, Y. (2007). Trends in pan evaporation and reference and actual evapotranspiration across the Tibetan Plateau. Journal of Geophysical Research, 112, D12110. http://dx.doi.org/10.1029/2006JD008161. 